\title{
Editorial
}

\section{Non-communicable diseases are reaching epidemic proportions: evidence from low and middle income countries}

In this September 2013 issue of African Health Sciences we bring you diverse papers with one running theme: communicable diseases. They cover a wide range of topics: from 'making plantains safe' for renal patients to sexuality for people surviving stroke.

Hence Eluwa et $\mathrm{al}^{1}$ report on the effect of diet soda drinks on the histology of the cerebellum, while Uganda researchers report on the effect of soaking plantain (matooke) to reduce its potassium content to make it safe for kidney disease patients. ${ }^{2}$ This is followed by biochemistry papers including one on inhibition of glucuronosyltransferase, ${ }^{3}$ bile acid metabolism ${ }^{4}$, the role of angiocidin in cell proliferation ${ }^{5}$, and paraoxonase and lipid hydroperoxide after football tournaments. ${ }^{6}$

The next group of papers is on cardiovascular issues. Hence we have a randomized controlled trial on the effect of interval training on pulse pressure in the management of hypertension. ${ }^{7}$ Patient related factors for optimal blood pressure control, ${ }^{8}$ and a non invasive test for left atrial thrombi in patients with mitral stenosis, ${ }^{9}$ are described. Others include the use of platelet volume in diagnosis of supraventricular tachycardia ${ }^{10}$; gender specific left ventricular adaptation to hypertension and obesity in a tertiary health facility in Nigeria. ${ }^{11}$ The section ends with two papers: serum zinc values in children with congenital heart disease ${ }^{12}$; and congenital heart diseases in children with pneumonia. ${ }^{13}$

The next set of papers is related to neurology. Duggan describes epilepsy and its effects on children and families in rural Uganda ${ }^{14}$; while Nigerian workers report on psychiatric morbidity in stroke patients attending a neurology $\operatorname{clinic}^{15}$.

Keeping with the theme on stroke, we have included papers on: the quality of life amongst young adults with stroke living in Kenya ${ }^{16}$; sexual dysfunctions in stroke survivors ${ }^{17}$; and factors associated with functional outcome of stroke patients after rehabilitation ${ }^{18}$.

Diabetes mellitus (DM): we have several papers on insulin resistance ${ }^{19}$; prednisolone induced $\mathrm{DM}^{20}$, foot ulcers and asymptomatic bacteriuria. ${ }^{21}$ One paper reports on effects of weight reduction on liver function and insulin resistance in DM with non-alcoholic fatty Liver. ${ }^{22}$ We conclude with effects of traditional Chinese medicine on type II DM induced by high-fat diet and streptozotocin. ${ }^{23}$ Allergy remains a big issue in African countries. Hence we have a report on the impact of weight loss on markers of inflammation in obese children with asthma. ${ }^{24} \mathrm{~A}$ hospital based study on garlic and onion sensitization ${ }^{25}$; and quality of life in patients with chronic obstructive pulmonary disease ${ }^{26}$ ends the section..

A treatise on non communicable disease is incomplete without consideration of cancer. Contributions include: prognostic value of glypican3 in alpha fetoprotein negative hepatocellular carcinoma patients ${ }^{27}$; immunohistochemical expression of EBV latent membrane protein and p53 in nasopharyngeal carcinoma ${ }^{28}$. Others are on environmental exposure to carcinogens in Cameroon ${ }^{29}$ and chronic inflammatory cells and damaged limbal basal epithelial cells in pterygium. ${ }^{30}$ The section on surgery and the GIT includes several interesting papers on factors affecting mortality of critical care trauma patients ${ }^{31}$; sarcoma of small bowel mesentery simulating hyper immune splenomegaly syndrome ${ }^{32}$; and upper GI bleeding among neonates ${ }^{33}$. There are more papers on use of a drain after thyroid surgery ${ }^{34}$; effect of bupivacaine on pulmonary function after elective lower abdominal operations ${ }^{35}$; camel related panceatico-duodenal injuries ${ }^{36}$; and postoperative pain in the first 48 hours. $^{37}$

Finally we have a section on substance abuse and the health system including: alcohol and substance use among adolescents in Ibadan, ${ }^{38}$ smokeless tobacco and tooth $\operatorname{loss}^{39}$; and substance use correlates of relapse among patients treated for addiction. ${ }^{40}$

Results of an evaluation of the effectiveness of the Zambian health worker retention scheme (ZHWRS) for rural areas ${ }^{41}$; teaching methods preferred by medical students ${ }^{42}$, factors influencing the choice of surgery as a career by pre-registration interns ${ }^{43}$, are reported. Patients' perceived reactions to medical errors $^{44}$, and returns from globalization to woman smallholder coffee and food producers in rural Uganda, ${ }^{45}$ ends this section. 
Finally we have case reports on medication errors in anesthetic practice ${ }^{46}$; vitamin B12 deficiency presenting with acute confusion ${ }^{47}$; and cases of jaundice with thyrotoxicosis. ${ }^{48}$

It is high time communicable diseases received the attention they deserve in the context of infections and dysfunctional health systems in LMICs.

\section{James K Tumwine}

Editor in Chief

African Health Sciences

Makerere University, College of Health Sciences

\section{References}

1. Eluwa AM, Inyangmme II, Akpantah AO, Ekanem BT, Asuquo OR, Ekong MB. A comparative study of the effect of diet and soda carbonated drinks on the histology of the cerebellum of adult female albino Wistar rats. African Health Sciences. 2013; 13(3): 541-5.

2. Asiimwe J, Sembajwe LF, Senoga A, Bakiika E, Muwonge H, Kalyesubula R. Overnight soaking or boiling of "Matooke" to reduce potassium content for patients with chronic kidney disease: does it really work? African Health Sciences. 2013; 13(3): 546-50.

3. Chengcheng G, Rui X, Tianheng M, Wei Y, Liqun PG. Probe substrate and enzyme sourcedependent inhibition of UDPglucuronosyltransferase (UGT) 1 A9 by wogonin. African Health Sciences. 2013; 3(3): 5515.

4. Shu-Yao Z, Hong J, Chao-Xian L, Zhi-Wei Z, Dai-Shan X, Lei C. In vitro evidence of possible influence of scutellarein towards bile acids metabolism. African Health Sciences. 2013; 13(3): 556-9.

5. Xingang $G$, Xinqiang $G$, Kai F, Rui J, Dan T HT, Xin Sun. Reduction of angiocidin contributes to decreased HepG2 cell proliferation. African Health Sciences. 2013; 13(3): 560-4.

6. Atli M. Serum paraoxonase activity and lipid hydroperoxide levels in adult football players after three days football tournament. African Health Sciences. 2013; 13(3): 565-70.

7. Lamina S, Okoye GC. Effect of interval training programme on pulse pressure in the management of hypertension: a randomized controlled trial. African Health Sciences. 2013; 13(3): 571-8.
8. Yi-Bing W, De-Gui K, Long-Le M, Le-Xin W. Patient related factors for optimal blood pressure control in patients with hypertension. African Health Sciences. 2013; 13(3): 579-83.

9. Rajappa M, Sunil Roy TN, Raj A, Trehan V, Mallika V. D-Dimer assay as a non invasive test for the diagnosis of left atrial thrombi in Indian patients with rheumatic mitro stenosis. African Health Sciences. 2013; 13(3): 584-9.

10. Ocak T, Erdem A, Duran A, Tekelioðlu U, Öztürk S, Ayhan S, et al. The importance of mean platelet volume in the diagnosis of supraventricular tachycardia. African Health Sciences. 2013; 13(3): 590-4.

11. Akintunde AA, Oladosu Y, Opadijo OG. Gender specific pattern of left ventricular cardiac adaptation to hypertension and obesity in a tertiary health facility in Nigeria. African Health Sciences. 2013; 13(3): 594-600.

12. Sadoh WE, Sadoh AE. Serum zinc values in children with congenital heart disease. African Health Sciences. 2013; 13(3): 601-6.

13. Sadoh WE, Osarogiagbon WO. Underlying congenital heart disease in Nigerian children with pneumonia. African Health Sciences. 2013; 13(3): 607-12.

14. Duggan MB. Epilepsy and its effects on children and families in rural Uganda. African Health Sciences. 2013; 13(3): 613-23.

15. Ajiboye PO, Abiodun OA, Tunde-Ayinmode MF, Buhari OIN, Sanya EO, Wahab KW. Psychiatric morbidity in stroke patients attending a neurology clinic in Nigeria. African Health Sciences. 2013; 13(3): 624-31.

16. Muli GG, Rhoda A. Quality of life amongst young adults with stroke living in Kenya. African Health Sciences. 2103; 13(3): 632-8.

17. Akinpelu AO, Osose AA, Odole AC, Odunaiya NA. Sexual dysfunction in Nigerian stroke survivors. African Health Sciences. 2013; 13(3): 639-45.

18. Joseph C, Rhoda A. Activity limitations and factors influencing functional outcome of patients with stroke following rehabilitation at a specialised facility in the Western Cape. African Health Sciences. 2013; 13(3): 646-54.

19. Akande TO, Adeleye JO, Kadiri S. Insulin resistance in Nigerians with essential hypertension. African Health Sciences. 2013; 13(3): 655-60.

20. Kotila TR, Olutogun T, Ipadeola A. Steroid induced diabetes mellitus in patients receiving 
prednisolone for haematological disorders. African Health Sciences. 2013; 13(3): 842-4.

21. Bisson MEA, Fon PN, Tabe-Besong FO, Akenji TN. Asymptomatic bacteriuria in diabetes mellitus patients in Southwest Cameroon. African Health Sciences. 2013; 13(3): 661-6.

22. Al-Jiffri O, Al-Sharif FM, Abd El-Kader SM, Ashmawy EM. Weight reduction improves markers of hepatic function and insulin resistance in type- 2 diabetic patients with nonalcoholic fatty liver. African Health Sciences. 2013; 13(3): 667-72.

23. Zhao H, Li Z, Tian G, GaoK, Li Z, Zhao B, et al. Effects of traditional Chinese medicine on rats with Type II diabetes induced by high-fat diet and streptozotocin: a urine metabonomic study African Health Sciences. 2013; 13(3): 67381.

24. Abd El- Kader MS, Al-Jiffri O, Ashmawy EM. Impact of weight loss on markers of systemic inflammation in obese Saudi children with asthma. African Health Sciences. 2013; 13(3): 6828.

25. Almogren A, Shakoor Z, Adam MH. Garlic and onion sensitization among Saudi patients screened for food allergy: a hospital based study. African Health Sciences. 2013; 13(3): 68993.

26. Obaseki DO, Erhabor GE, Awopeju OF, Obaseki JE, Adewole OO. Determinants of health related quality of life in a sample of patients with chronic obstructive pulmonary disease in Nigeria using the St. George's respiratory questionnaire. African Health Sciences. 2013; 13(3): 694-702.

27. Li B, Liu H, Shang HW, Li P, Li N, Ding HG. Diagnostic value of glypican-3 in alpha fetoprotein negative hepatocellular carcinoma patients. African Health Sciences. 2013; 13(3): 703-19.

28. Tabyaoui I, Serhier Z, Sahraoui S, Sayd S, Cadi $\mathrm{R}$, Bennani OM, et al. Immunohistochemical expression of latent membrane protein 1 (LMP1) and p53 in nasopharyngeal carcinoma: Moroccan experience. African Health Sciences. 2013; 3: 710-7.

29. Nsagha S, Sasco A, Kamga H L, Nguedia C, Assob J, Njunda A. Environmental exposure to carcinogens in northwestern Cameroon. African Health Sciences. 2013; 3(3): 718-24.
30. Anguria P, Carmichael T, Ntuli S, Kitinya J. Chronic inflammatory cells and damaged limbal cells in pterygium. African Health Sciences. 2013; 13(3): 725-30.

31. Hefny AF, Idris K, Eid HO, Abu-Zidan FM. Factors affecting mortality of critical care trauma patients. African Health Sciences. 2013; 13(3): 731-5.

32. Alatise OI, Oke OA, Olaofe OO, OmoniyiEsan GO, Adesunkanmi ARK. A huge lowgrade fibromyxoid sarcoma of small bowel mesentery simulating hyper immune splenomegaly syndrome: a case report and review of literature. African Health Sciences. 2013; 13(3): 736-40.

33. Ombeva MO, Ndeezi G, Mugalu J. Upper GI bleeding among neonates admitted to Mulago Hospital, Kampala, Uganda: a prospective cohort study. African Health Sciences. 2013; 3: 741 7.

34. Kalemera Ssenyondo E, Fualal J, Jombwe J, Galukande M. To drain or not to drain after thyroid surgery: a randomized controlled trial at a tertiary hospital in East Africa. African Health Sciences. 2013; 13(3): 748-55.

35. Ige O, Bolaji B, Olawole I. Effect of wound infiltration with bupivacaine on pulmonary function after elective lower abdominal operations. African Health Sciences. 2013; 13(3): 756-61.

36. Abu-Zidan FM, Hefny AF, Mousa H, Torab FC, Hassan I. Camel-related pancreaticoduodenal injuries: a report of three cases. African Health Sciences. 2013; 13(3): 762-7.

37. Mwaka G, Thikra S, Mung'ayi V. The prevalence of postoperative pain in the first 48 hours following day surgery at a tertiary hospital in Nairobi. African Health Sciences. 2013; 13(3): 76876.

38. Atilola O, Ayinde O, Adeitan O. Beyond prevalence and pattern: problematic extent of alcohol and substance use among adolescents in Ibadan South-west Nigeria. African Health Sciences. 2013; 13(3): 777-84.

39. Agbor MA, Azodo CC, Tefouet TSM. Smokeless tobacco use, tooth loss and oral health issues among adults in Cameroon. African Health Sciences. 2013; 13(3): 785-90.

40. Manabendra S, Amanda M, Nirmalya M, Sandip S. Sociodemographic and substance use correlates of repeated relapse among patients presenting for relapse treatment at an addiction 
treatment center in Kolkata, India. African Health Sciences. 2013; 13(3): 791-9.

41. Gow J, George G, Mwamba S, Ingombe L, Mutinta G. An evaluation of the effectiveness of the Zambian Health Worker Retention Scheme (ZHWRS) for rural areas. African Health Sciences. 2013; 13(3): 800-7.

42. Papanna KM, Kulkarni V, Tanvi D, Lakshmi V, Kriti L, Unnikrishnan B, et al. Perceptions and preferences of medical students regarding teaching methods in a Medical College, Mangalore India. African Health Sciences. 2013; 13(3): 808-13.

43. Lawal TA, Afolabi AO. Factors influencing the choice of surgery as a career by pre-registration interns. African Health Sciences. 2013; 13(3): 8149 .

44. Ushie BA, Salami KK, Jegede AS, Oyetunde M. Patients' knowledge and perceived reactions to medical errors in a tertiary health facility in Nigeria. African Health Sciences. 2013; 13(3): 820-

8.
45. Kanyamurwa JM, Wamala S, Baryamutuma R, Kabwama E, Loewenson R. Differential returns from globalization to women smallholder coffee and food producers in rural Uganda. African Health Sciences. 2013; 13(3): 82941.

46. Ogboli-Nwasor E. Medication errors in anaesthetic practice: a report of two cases and review of the literature. African Health Sciences. 2013; 13(3): 845-9.

47. Kibirige D, Wekesa C, Kaddu-Mukasa M, Waiswa M. Vitamin B12 deficiency presenting as an acute confusional state: a case report and review of literature. African Health Sciences. 2013; 13(3): 850-2.

48. Akande TO. A report of three cases of jaundice with thyrotoxicosis. African Health Sciences. 2013; 13(3): 853-6. 